\title{
A patient charter of rights: how to avoid a toothless tiger and achieve system improvement
}

\author{
Colleen M. Flood LLM SJD, Kathryn May HBSC
}

$\mathrm{A}$ s part of the movement toward patientcentred care, several countries have adopted charters of rights for patients. Unlike the Canadian Charter of Rights and Freedoms, patient charters do not generally grant formal legal rights. Instead, they can act as a catalyst through which to resolve individual patient concerns quickly and economically. In addition, a properly designed patient charter can be a mechanism to spur overall system improvements. Despite this potential, Quebec is the only Canadian province that has implemented a patient charter, ${ }^{1,2}$ although Alberta is now in the process of establishing one. ${ }^{3}$

To explore the potential for a patient charter (sometimes also referred to as a patient bill of rights) to be a galvanizing force for system im provement, we collected literature on governmentenacted patient charters across 39 jurisdictions (Appendix 1, available at www.cmaj.ca/lookup /suppl/doi:10.1503/cmaj.111050/-/DC1). We con ducted a keyword search of PubMed, Google Scholar, Westlaw Canada and Quicklaw, using search terms such as "bill of patient rights," "charter of patient rights," "ombudsman" and "complaints commissioner," focusing primarily on publications within the past 15 years. We searched for publications detailing the contents of patient charters in various jurisdictions, in addition to publications assessing the outcomes of the implementation of such charters. We also looked directly at pa tient's rights legislation from different jurisdictions. Our focus was on national or provincial/state-level patient charters, as opposed to more local initiatives at the regional or hospital level.

As we discuss here, the success or otherwise of a patient charter depends heavily on its design, the nature of the rights enumerated, the interaction between the charter and other disciplinary and legal channels, and the scope of the charter's mandate to address systemic problems in health care. Most important of all are the mode and means by which patients can have their "rights" realized or, more accurately, their concerns heard. Without a reliable and affordable enforcement mechanism, a patient charter is little more than a toothless tiger.

\section{Scope of rights}

To be effective, patients' rights must be articulated clearly. Some patient charters contain long lists of rights but lack organization and clarity, creating confusion for patients and health care providers alike. ${ }^{4}$

Patient charters typically include rights that already exist in the common law and those that are scattered across a variety of statutes. The charter thus provides a mechanism to consolidate existing patient rights, such as the right to informed consent, the right to access one's own health information and the right to privacy. What a patient charter typically adds that may not be presently available is the right for patients to have their complaints investigated by an independent body. These are rights "in" health care; that is, they implicate how a patient experiences care within the present offerings of the health care system. ${ }^{5}$ Although patients already posess many of these rights, they are given greater clarity and publicity by being included in one document. Where a charter can add particular value is in allowing patients to realize these rights without the expense and delay of lawyers and courts.

A patient charter may also include rights "to" health care. Such rights are more controversial, as they may seem to empower patients to demand health care or timely treatment as a right. Such guarantees, if phrased or interpreted inappropriately, could quickly encounter re source constraints. ${ }^{6}$ To meet this concern, rights
Competing interests: Colleen Flood has received grant funding from the Canadian Institutes of Health Research. No other competings interests were declared.

This article has been peer reviewed.

Correspondence to: Colleen Flood, colleen.flood@utoronto.ca

CMAJ 2012. DOI:10.1503 /cmaj.111050 
to health care in patient charters are generally expressed as limited by resource constraints. For example, Finland's Act on the Status and Rights of Patients grants a patient a right to

the health and medical care required by his state of health within the limits of those resources which are available to health care at the time in question. ${ }^{7}$

Of course, the ability to draw attention to patient concerns about resource constraints may help policy-makers and the public identify inappropriate decisions regarding the allocation of resources and spur change.

An increasingly common approach to drafting a patient charter is to provide for rights to timely treatment. Where these rights have been created, there have often been dramatic improvements in wait times, although this is always as part of a broader package of reforms geared to reducing wait times. In Norway, for example, between 2001 (the year Norway's Patients' Rights Act was introduced) and 2006, wait times for specialist care dropped by nearly 30\%. ${ }^{8}$ Similarly, England's National Health Service introduced waittime targets in 2000; by 2007, there had been an $82.2 \%$ decline in the number of inpatients waiting more than 13 weeks for treatment, and a $99.6 \%$ decline in the number of outpatients waiting more than 13 weeks. ${ }^{9}$ However, there is concern that a focus on timeliness comes at the expense of prioritizing patients in greater need. For example, in England, decreases in wait times for certain patients appeared to come at the expense of increases in wait times for others, although there has been a considerable decline in the frequency of such trade-offs in recent years. (It is worth noting, however, that wait-time goals in Canada at the provincial level do not seem to have diverted resources unnecessarily. $)^{10}$ Tellingly, although the English government moved to abolish certain key wait-time targets in 2010, citing concerns that such guarantees had detrimental effects on patient prioritization, ${ }^{11}$ the decision has since been reversed, on the grounds that the benefits associated with wait-time guarantees outweigh the flaws. ${ }^{12}$

Another important question concerns whether patient rights are enforceable in the context of privately financed care. Most patient charters are focused on the public health care system. Quebec's Act Respecting Health Services and Social Services (which articulates patient rights) and complaints system, for example, only apply to the public sector. ${ }^{13,14}$ Clearly, as the privately financed sector expands across a range of services (e.g., cosmetic surgery, diagnostics, longterm care), it is important that patients have reasonable means through which to make complaints and have them speedily resolved. There have already been promising initiatives in recognition of this need: New Zealand's Code of Health and Disability Services Consumers' Rights covers both the public and private sectors, ${ }^{15}$ and Finland's Act on the Status and Rights of Patients requires every health care unit, both public and private, to appoint a patient ombudsman. ${ }^{16}$

\section{Concerns of health care professionals}

Health care professionals may be concerned that codifying patients' rights will lead to an increase in disciplinary measures and/or litigation. Certainly, countries such as New Zealand, ${ }^{17}$ Denmark $^{18}$ and Norway ${ }^{18}$ have seen an increase in the number of complaints made by patients. However, patient charters with dedicated complaints processes enable matters to be resolved at an early stage by informal means, averting the need for litigation or formal disciplinary proceedings. ${ }^{4,19}$ For example, in the three years before New Zealand enacted its code in 1996, the relevant tribunal for physicians received an annual average of 84 disciplinary charges; by 2010, after the code was enacted, the average dropped to $8 .{ }^{15}$ This staggering decline is partly due to the commissioner's role as gatekeeper to the more formal disciplinary proceedings, providing a more immediate and expedient venue for voicing complaints, and focusing on low-level resolution. ${ }^{15}$ In addition, the Medical Council of New Zealand and other registration bodies use competence reviews to address performance issues (under the Health Practitioners Competence Assurance Act 2003), rather than resorting to disciplinary processes. ${ }^{20}$ Thus, a properly designed patient charter is a win-win proposition for patients and health care professionals alike.

Health care professionals often ask for patient responsibilities to be included alongside patient rights. It is suggested that patients have a responsibility to promote their own health, to fully disclose their medical history to providers and to treat providers with respect. ${ }^{21}$ Some people object, however, stating that the inclusion of patient responsibilities is paternalistic, undermines patient empowerment and is overly burdensome to vulnerable groups. ${ }^{22}$ At any rate, it is not clear that such responsibilities can be monitored and enforced ${ }^{23}$ Still, it is possible that the inclusion of patient responsibilities may have a larger normative or cultural effect - one that is difficult to measure, but nonetheless important. 


\section{Ready access to independent review}

The evidentiary burdens, costs and delays associated with ordinary litigation make it an impractical means for enforcing patient rights. Moreover, patients cannot readily bring litigation against system actors (such as governments) for resource allocation decisions. If a patient charter of rights is to be meaningful, it must provide patients with an inexpensive, readily accessible, independent means by which to file a complaint and have it quickly resolved.

Many Canadian hospitals have voluntarily put in place mechanisms for resolving patient complaints. For example, Toronto East General Hospital has a code of patient rights and responsibilities, which includes common patient rights such as access to information about one's care, involvement in decisions about one's care and maintenance of the confidentiality of one's health records. ${ }^{24}$ However, patients may question the independence of these internal processes given the institution's interest in protecting its own reputation and its close relationship with medical staff. Consequently, it is important that patients have recourse to an adjudicative body they perceive as impartial if they are unhappy with how their concerns or complaints have been handled at a local level. Accordingly, most countries with patient charters have established independent patient ombudsmen or commissioners to resolve complaints using a variety of informal and formal mechanisms. For example, in New Zealand, the health and disability commissioner uses various methods of dispute resolution (advocacy, mediation, etc.), with a focus on promoting resolution directly between providers and patients. A key ingredient to the success of a patient charter is a well-resourced and responsive ombudsman; lack of sufficient resources and training among ombudsmen has been one of the most common concerns across jurisdictions. ${ }^{16}$

\section{Patient rights are not enforceable}

Although a patient charter lists patient "rights," in most jurisdictions, an ombudsman or commissioner is not empowered to make binding recommendations. In other words, these agents don't "enforce" rights (e.g., unlike a court, they can't award damages); instead, they rely on moral suasion to effect change. Nonetheless, international experience is generally positive as to the ability of an ombudsman or commissioner, through recommendations and findings alone, to achieve system improvements.
In New Zealand, health care institutions and professionals have largely been receptive to the commissioner's recommendations. ${ }^{25}$ Both providers and the public tend to view the commissioner's decisions as having weight comparable with that of court judgments. ${ }^{15}$ Similarly, the 2009-2010 annual report of the Quebec ombudsman found that more than $98 \%$ of recommendations vis-à-vis patient complaints had been accepted on the part of the relevant health care providers. ${ }^{26} \mathrm{~A}$ partial explanation for this success may be that an ombudsman whose recommendations are not binding makes the complaints process less contentious, and health care providers are thus more receptive to the process than if it were binding and more adversarial. Furthermore, an ombudsman or commissioner can also provide the media with the names of institutions found to have breached patients' rights, creating a reputational incentive for compliance. ${ }^{15,27}$

\section{Driving systemic improvement}

In 2010, the Canadian Medical Association endorsed a proposal for a national charter of patients' rights. ${ }^{28}$ The draft Charter for PatientCentred Care contains rights pertaining not only to the provider-patient relationship, but also to the relationship between the patient and the health care system at large, such as continuity of care between providers, transparency in government decision-making on the delivery of health care, and proactive monitoring and quality improvement. ${ }^{29}$ But how are these rights realized? To drive system-level improvements, international experience suggests that it is important for an ombudsman or commissioner to have an information-gathering function with respect to system issues and to advise health care institutions, the government and the public on pertinent matters.$^{30}$ In addition, in the pursuit of a more patient-centred system, an ombudsman is typically required to publicly promote the observance of patients' rights and to issue public reports on matters affecting patients.

Prominent jurisdictions in which an ombudsman or commissioner holds a system-improvement role include New Zealand, ${ }^{30}$ Hungary, ${ }^{31}$ Quebec, ${ }^{13,32}$ Finland, ${ }^{16}$ Norway ${ }^{33}$ England ${ }^{34}$ and Israel. ${ }^{16}$ In England, the 2010 Stakeholder Impact Study on the Parliamentary and Health Service ombudsman (PHSO) found that "PHSO recommendations have sufficient credibility and gravitas to influence senior decision-makers." ${ }^{35}$ Ontario's Psychiatric Patient Advocate Office, tasked with promoting the civil and legal rights of patients with psychiatric conditions, is another example of a widely recognized driver of systemic change. By issuing reports 
and recommendations, the office has influenced policy decisions on such issues as the hospital management of patient funds and the use of tasers. More broadly, the office has helped change perceptions of mental illness and the rights of people with mental illness. Patients are now accorded more involvement in treatment decisions, which may in turn increase their adherence to treatment plans. ${ }^{36}$

Thus, an ombudsman's power of moral suasion - though lacking in enforceability - may have a broader and more systemic impact than individualized disciplinary hearings or litigation. ${ }^{37}$ A caveat to this is the experience in Quebec; although the resolution of concerns vis-à-vis health care providers seems to function well, the same cannot be said of other system actors. As of Mar. 31,2010 , the ombudsman deemed that responses to 13 of 25 recommendations from 2007-2008 made by the ombudsman on the part of the Ministry of Health and Social Services were still unsatisfactory, as were the responses to all 7 recommendations from 2008-2009. ${ }^{26}$ However, there may be other factors impeding a timely response from the government of Quebec, and we do not know what the alternative would be in the absence of the ombudsman's work - there could be even less responsiveness.

Given the success other jurisdictions have had with independent review as a means to spur improvement, it is disappointing that Alberta did not take the opportunity in its recently enacted patient rights legislation to clearly provide for a form of third-party review of governmental and system performance. ${ }^{3}$ Instead, it limited the scope of its charter to patient complaints vis-àvis health care providers and health authorities. ${ }^{3}$

\section{Conclusion}

A patient charter of rights should achieve greater clarity and awareness of the nature and extent of patients' rights; if well designed, it should also help drive improvements in the quality and timeliness of care, improve the overall accountability of members of the health care system and reduce costly litigation. However, experience shows that it is easy for a patient charter to be a toothless tiger - that is, a mechanism to merely talk about improving the patient experience and re forming the health care system. To be effective, it is essential that patients have access to an independent ombudsman or commissioner who can quickly and economically resolve their complaints or concerns.

Health care professionals worried about a culture of complaint should be reassured by evidence that alternative mechanisms for dispute resolution substantially avert subsequent formal disciplinary complaints, so that both patients and health care professionals are winners. Moreover, an ombudsman or commissioner, armed with powers to gather information, can also weigh in on systemic matters such as resource allocation, wait times and safety issues. The international evidence here is more mixed, but it suggests that moral suasion from a sufficiently resourced and independent ombudsman or commissioner can positively drive system change.

\section{References}

1. Vogel L. Patient charters: the provincial experience. CMAJ 2010;182:E639-40.

2. An Act Respecting Health Services and Social Services, RSQ 1991 , c. s-4.2, s. 4

3. Alberta Health Act, SA 2010, c. A-19.5.

4. Mujovic-Zornic H. Legislation and patients' rights: some necessary remarks. Med Law 2007;26:709-19.

5. Flood C, Epps T. A patients' bill of rights: A cure for Canadians' concerns about Medicare? Policy Matters 2002;3:1-44.

6. Newdick C. Priority-setting: assessing the risks of the NHS constitution [memorandum]. London (UK): United Kingdom Parliament; 2009. Available: www.publications.parliament.uk/pa $/ \mathrm{cm} 200809 / \mathrm{cmselect} / \mathrm{cmhealth} / 194 \mathrm{i} / 194 \mathrm{iwe} 11 . \mathrm{htm}$ (accessed 2011 May 22).

7. Act on the Status and Rights of Patients 1992 (Finland), c 2, s 3. Available: www.finlex.fi/en/laki/kaannokset/1992/en19920785 .pdf (accessed 2011 June 30).

8. Norwegian Ministry of Health and Care Services. National health plan for Norway (2007-2010). In: Proposition to the storting no. 1 (2006-2007). Oslo (Norway): The Ministry; 2007. Available: www.regjeringen.no/upload/HOD/National\%20 health\%20plan_eng_06052007.pdf (accessed 2011 June 14).

9. Harrison A, Appleby J. Reducing waiting times for hospital treatment: lessons from the English NHS. J Health Serv Res Policy 2009; $14: 168-73$

10. Canadian Institute for Health Information. Waiting for health care in Canada: what we know and what we don't know. Ottawa $(\mathrm{ON})$ : The Institute; 2006. Available: secure.cihi.ca/cihiweb /products/WaitTimesReport_06_e.pdf (accessed 2011 June 14).

11. Ramesh R. NHS waiting-time targets scrapped by Andrew Lansley. The Guardian [London (UK)] 2010 June 21. Available: www.guardian.co.uk/politics/2010/jun/21/nhs-waiting-time-targets -scrapped (accessed 2011 June 22).

12. Timmins N. Targets on NHS waiting times revived. Financial Times [London (UK)] 2011 June 7. Available: www.ft.com/intl/cms/s /0/388cc0b0-9138-11e0-9668-00144feab49a.html\#axzz1lc9vkQfR (accessed 2011 June 22).

13. Régis C. Enhancing patients' confidence in access to health care: the Ontario or Québec way? Health Law J 2004;12:243-73.

14. Health and Social Services Network Agencies and Authorities. Québec (QC): The Ombudsman; 2010. Available: www protecteurducitoyen.qc.ca/en/filing-a-complaint/concerning-the -health-and-social-services-network/index.html (accessed 2011 June 15).

15. Skegg PD. A fortunate experiment? New Zealand's experience with a legislated code of patients' rights. Med Law Rev 2011;19: 235-66.

16. Mackenney S, Fallberg L, eds. Protecting patients' rights? A comparative study of the ombudsman in healthcare. Oxon (UK): Radcliffe Medical Press; 2004.

17. New Zealand Health and Disability Commissioner. Annual report for the year ended 30 June 2010. Auckland (New Zealand): The Commissioner; 2010. Available: www.parliament .nz/NR/rdonlyres/6BBCE7BC-8257-4AC0-B7B8-869FBF7357EF /173291/DBHOH_PAP_20895_HealthandDisabilityCommissioner TeT.pdf (accessed 2011 June 1 ).

18. Magnussen J, Vrangbaek K, Saltman RB, editors. Nordic health care systems: recent reforms and current policy challenges. New York (NY): McGraw-Hill Open University Press; 2009.

19. The ever-growing challenge of medical liability: national and European responses. Proceedings of the Council of Europe; 2008 June 2-3; Strasbourg. Strasbourg (France): Directorate General of Human Rights and Legal Affairs, Council of Europe; 2009.

20. Collins D, Brown C. The impact of the Cartwright Report upon the regulation, discipline and accountability of medical practitioners in New Zealand. J Law Med 2009;16:595-613. 
21. Schmidt H. Patients' charters and health responsibilities. $B M J$ 2007;335:1187-9.

22. Schmidt H. Personal responsibility in the NHS Constitution and the social determinants of health approach: Competitive or complementary? Health Econ Policy Law 2009;4:129-38.

23. Schmidt H. Just health responsibility. J Med Ethics 2009:35:21-6.

24. Patient Rights and Responsibilities. Toronto (ON): Toronto Eas General Hospital. Available: www.tegh.on.ca/bins/content_page .asp?cid=2-459 (accessed 2011 June 14)

25. Sladden N, Graydon S. Liability for medical malpractice recent New Zealand developments. Med Law 2009;28:301-15.

26. Annual report 2009-2010. Québec (QC): The Ombudsman; 2010. Available: www.protecteurducitoyen.qc.ca/en/cases-and -documentation/index.html (accessed 2011 May 31).

27. Office of the Health and Disability Commissioner. Statement of intent 2010-2013. Auckland (New Zealand): The Office; 2010. Available: www.hdc.org.nz/media/161539/2010-2013\%2028 \%20june\%202010.pdf (accessed 2011 June 15).

28. Vogel L. Doctors endorse development of patient charter. CMAJ 2010;182:E655-6

29. Canadian Medical Association. Health care transformation in Canada: change that works, care that lasts. Ottawa $(\mathrm{ON})$ : The Association; 2010. Available: www.cma.ca/multimedia/CMA /Content_Images/Inside_cma/Advocacy/HCT/HCT-2010report_en .pdf (accessed 2011 May 11)

30. Paterson R. The patients' complaints system in New Zealand. Health Aff (Millwood) 2002;21:70-9.

31. Fábián T. Patient advocacy system in Hungary. Med Law 2004 23:797-804.

32. Strategic plan 2009-2012. Québec (QC): The Ombudsman; 2009 Available: www.protecteurducitoyen.qc.ca/fileadmin/medias /pdf/StrategicPlan_eng_72dpi.pdf (accessed 2011 June 15).
33. Johnsen JR. Health systems in transition: Norway. Geneva (Switzerland): World Health Organization 2006, on behalf of the European Observatory on Health Systems and Policies; 2006. p. 1-167.

34. Parliamentary and Health Service Ombudsman. Listening and learning: the ombudsman's review of complaint handling by the NHS in England 2009-10. London (UK): The Ombudsman; 2010. Available: http://nhsreport.ombudsman.org.uk /assets/files/downloads/Listening_and_Learning_HC482-PHSO -0110.pdf (accessed 2011 June 10).

35. Parliamentary and Health Service Ombudsman. Impact study presentation of findings. London (United Kingdom): The Ombudsman; 2010. Available: www.ombudsman.org.uk/ data/assets /pdf_file/0013/4144/Impact-Study.pdf (accessed 2011 June 10).

36. Psychiatric Patient Advocate Office. Honouring the past, shaping the future: 25 Years of progress in mental health advocacy and rights protection. Toronto (ON): The Office; 2008. Available: www.sse.gov.on.ca/mohltc/PPAO/en/Documents/pub-ann-25.pdf (accessed 2012 Jan. 12).

37. Bismark MM, Studdert DM. Realizing the research power of complaints data. N Z Med J 2010;123:12-7.

Affiliations: From the Faculty of Law (Flood, May), University of Toronto, Toronto, Ont.

Contributors: Kathryn May conducted the literature research and was involved in drafting the paper and approving the final version submitted for publication. Colleen Flood conceptualized the structure and thesis of the paper, drafted and revised it, and approved the final version submitted for publication. 